\title{
Interaction of lysine dendrimer with 8 and 16 molecules of EDR peptide
}

\author{
V.V. Bezrodnyi, E.I. Fatullaev, S.E. Mikhtaniuk, I.I. Tarasenko, I.M. Neelov
}

\begin{abstract}
Dendrimers are frequently used for drug molecules delivery to different cells or organs. In our previous papers we used computer simulation to study the complex formation between dendrimers and dendrigrafts with different short regulatory peptides. The goal of present paper is to study interaction and the possibility of complex formation between lysine dendrimer and molecules of therapeutic EDR peptide. The system consisting of one lysine dendrimer of the second generation and 8 or 16 therapeutic EDR peptide molecules in water with explicit counterions was studied by computer simulation. The method of molecular dynamics and full atomic model were used for this goal. It was obtained that EDR peptide molecules become adsorbed by lysine dendrimer and form stable complex with it. Structure and conformational properties of this complex were studied. It was demonstrated that formation of complex occurs mainly due to electrostatic interaction between oppositely charged dendrimer and peptide molecules. Such complexes could be used in future for delivery of these or similar peptide molecules to the targeted tissues and organs.
\end{abstract}

Key-Words: - lysine dendrimer, EDR peptide, complex, molecular dynamics simulation

\section{INTRODUCTION}

Therapeutic EDR peptide was selected for our study as a model peptide. These peptides are novel synthetic peptides that display neuroprotecting activity [1-4]. Today one of the most important directions in pharmaceutics is the search for new biocompatible carriers for targeted delivery of various drugs (including therapeutic peptides) to particular organs. Highly branched polymer macromolecules including dendrimers and dendrimers are good candidates for this goal.

V.V. Bezrodnyi, E.I. Fatullaev and I.M.Neelov are supported by RFBR grant 20-53-12036. I.I.Tarasenko worked accordingly to State Assingment of IMC RAS. V.V.Bezrodnyi, E.I.Fatullaev, S.E.Mikhtaniuk and I.M.Neelov, are with ITMO University, St. Petersburg, Russia (e-mail: i.neelov@mail.ru , tel.+7 9627207977 ); I.I.Tarasenko is with Institute of Macromolecular Compounds RAS, , St. Petersburg, Russia (e-mail: itarasenko@list.ru). Participants from ITMO University are grateful for subsidy 08-08 of Government of Russian Federation.
Dendrimers are special class of hyperbranched macromolecules which are regularly branched from single central core. Lysine dendrimers consists entirely of biocompatible lysine aminoacid residues. At the same time their terminal groups could be functionalized by other aminoacid residues or by bioactive groups or molecules. Lysine dendrimers are polymers that are rich with amines. Due to this reason they could be used as antibacterial or antiviral agents. Also they could make complexes with oppositely charged peptides due to strong electrostatic interaction between their positively charged terminal groups (NH3+) of dendrimer and negatively charged aminoacid side groups (COO-) of peptide molecules.

During the process of complex formation with regulatory peptides, there are several possible types of interactions: electrostatic interaction between positively charged $\mathrm{NH} 3+$ side groups of and negatively charged COO- side groups of peptide molecules, hydrogen bonds between the internal groups of dendrimer and amino acid residues and hydrophobic interactions between nonpolar groups. The aim of this work is to study properties of system, consisting of lysine dendrimer and EDR peptide molecules in water. The main goal of this paper is to check does dendrimer forms complex with EDR peptide molecules and, if yes, to determine the size and other equilibrium characteristics of it.

\section{Method of Molecular DyNAMICS}

Molecular dynamics (MD) method is currently the main computer simulation method for study polymer and biopolymer systems. The method consists in numerical solution of the classical Newton equations of motion for all atoms of the all molecules in the system. In present paper simulation was performed for systems consisting of one lysine dendrimer of second generation with 16 positively charged $\mathrm{NH} 3+$ end groups and 8 or 16 EDR peptide molecules (with overall charge of each peptide 
molecule equals to -1). These molecules were placed in water box (cubic cell with periodic boundary conditions) with corresponding number of counterions. The initial conformation of dendrimer was taken from the end of long simulation of single dendrimer in water (without peptide molecules). For peptide molecules the initial conformation with dihedral angles $\varphi=-135^{\circ}, \psi=135^{\circ}, \theta=180^{\circ}$ was prepared using AVOGADRO molecular editor. The structures of peptides were first optimized in vacuum using molecular mechanics of AMBER force field. Further energy minimization and simulations of whole system was performed using the GROMACS software package [3] and AMBER_99SB-ildn force fields [4]. The potential energy of this force field consists of valence bonds and angles deformation energy, internal rotation angles, van der Waals and electrostatic interactions. In present simulations we used LINCS algorithm to constraint all valence bonds and increase the discretization time to 0.002 ps. For calculation of non-bonded interaction and, in particular, electrostatic ones we use particle mesh Ewald algorithm (PME) which allows correct calculations of long-range Coulomb potential. We calculated trajectory of all atoms during 100ns time and used first half of it for study of complex formation and second half for calculation of equilibrium average values of different parameters (size, shape and internal structure) of complex

We perform all simulation in NPT ensemble and at normal conditions (temperature $300 \mathrm{~K}$ and pressure 1 ATM). The procedure of molecular dynamics simulation for lysine dendrimers and for other linear and branched polymers and polyelectrolytes has been described earlier in [5-67] and further details about simulations could be found there.

\section{COMPLEX FORMATION}

Snapshots of a subsystem consisting of dendrimer of second generation and 8 or 16 peptide molecules at the beginning (figs. 1a, 1c) and at the end of simulation (figs. 1b, 1d) are shown on fig. 1. It is clearly seen that at the beginning of simulation (fig. 1a) all peptide molecules are far from dendrimer. At the same time in the end of simulation (fig. $1 \mathrm{~b}$ and fig.1d all peptide molecules are adsorbed on dendrimer surface.

To characterize the size of the subsystems consisting of dendrimer of second generation and 8 or 16 peptide molecules the instant square of radius of gyration $R_{g}(t)$ was used. The time dependence of gyration radius $R_{g}(t)$ of subsystem consisting of dendrimer and peptide molecules describes the process of equilibration and demonstrate the kinetics of complex formation (if formation of complex occurs) or separation of dendrimer and peptide molecules (if it is not occurs). It can be seen from fig. $2 a$, and fig. $2 b$ that in the beginning of simulation the value of $R_{g}(t=0)$ equal about $4.5 \mathrm{~nm}$ for first subsystem and about 5,0nm for second one. These values of $R_{g}$ are rather big because peptides are far from dendrimer (see fig.1a and fig.1c).

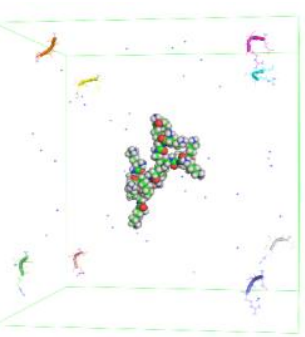

(a)

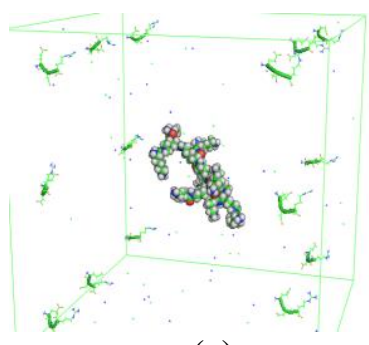

(c)

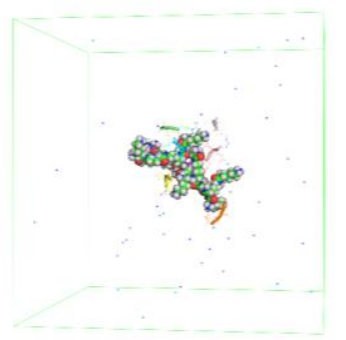

(b)

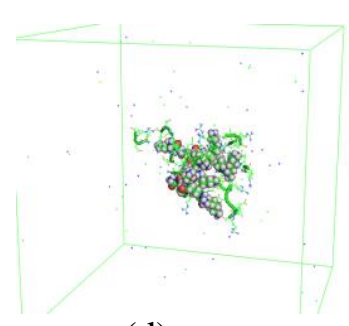

(d)
Fig. 1. Snapshots of initial $(a, c)$ and final $(b, d)$ conformations of lysine dendrimer of 2nd generation and 8 EDR peptides $(\mathrm{a}, \mathrm{b})$ or 16 EDR peptides $(\mathrm{c}, \mathrm{d})$

After that the radius of gyration of the subsystems become smaller and smaller because peptide molecules attracted by dendrimer become more and more close to it due to strong intermolecular interactions. The slope of $\mathrm{R}_{\mathrm{g}}(\mathrm{t})$ could characterize in this stage the rate of complex formation. Finally, the value of $\mathrm{R}_{\mathrm{g}}(\mathrm{t})$ goes to plateau value because all peptide molecules become adsorbed on dendrimer surface. For both systems it occurs at time about 3040 ns. After that, the complexes sizes $R_{\mathrm{g}}$ fluctuate, but their average values practically do not change with time.

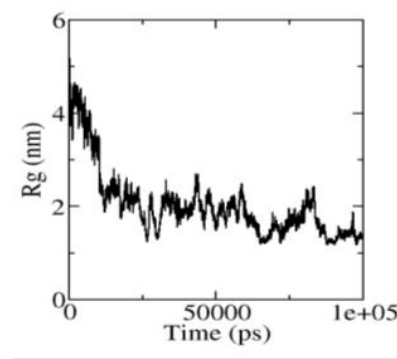

(a) (b)

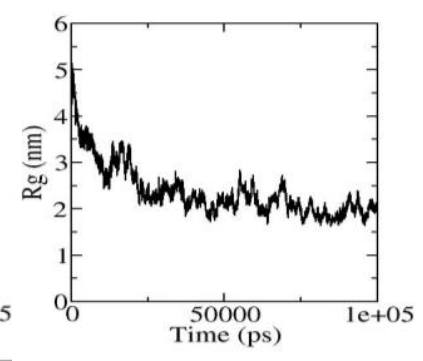




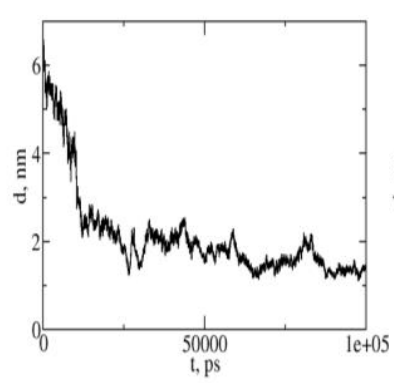

(c)

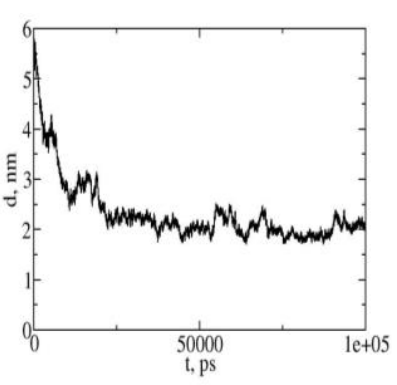

(d)
Fig 2. a) Time dependence of gyration radius $R_{g}(t)$ of complex with 8EDR (a) and with16EDR (b); distance between dendrimer and peptide molecules in first complex(c) and in second complex(d).

$\mathrm{R}_{\mathrm{g}}(\mathrm{t})$ was calculated using g_gyrate function of GROMACS.

The time dependence of distance between dendrimer and peptide molecules (fig.2c and fig.2d for first and second system correspondingly) has similar behaviour. Distances are rather big at the beginning of simulation/ After that they decrease during about 30-40 ns. The slope of time dependence of distance could also characterize the rate of complex formation. After first 30-40ns the distances fluctuates but their average value practically does not change with time. Therefore, we can assume that the systems are in equilibrium state after first $40 \mathrm{~ns}$ of computer simulation and calculate equilibrium value of $\operatorname{Rg}=\operatorname{sqrt}\left(\left\langle\mathrm{R}_{\mathrm{g}}{ }^{2}(\mathrm{t})\right\rangle\right)$ (where $<>$ mean average on equilibrium (plateau) part of trajectory, i.e. for $\mathrm{t}>15 \mathrm{~ns}$ and calculate equilibrium distance between dendrimer and peptide molecules). Function "distance" was calculated using g_bond function of GROMACS package.

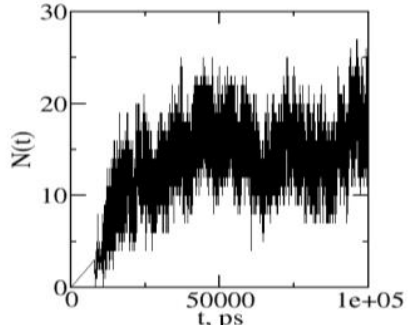

(a)

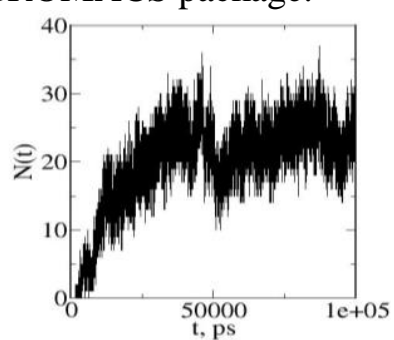

(b)
Fig.3 Time dependence of hydrogen bonds number (N) between dendrimer G2 and 8EDR peptides (a) and G2 with 16EDR peptides (b) during the complex formation

Another quantity that can demonstrates kinetics of complexes formation and confirm that the complex formation between dendrimer and peptide molecules really occurs is the time dependence of number of hydrogen bonds $\mathrm{N}$ between (see dendrimer and peptides (fig.3a for first system and fig $3 b$ for second system). In the beginning of simulation the value of $\mathrm{N}(\mathrm{t}=0)=0$ because dendrimer and EDR peptides are far from each other and thus do not have any contacts. When peptide molecules become closer to dendrimer the contacts between them appears and the value of $\mathrm{N}(\mathrm{t})$ start to increase with time. Thus, the slope of $\mathrm{N}(\mathrm{t})$ also could characterize the rate of complex formation. After time $\mathrm{t}=30-40 \mathrm{~ns}$ the function $\mathrm{N}(\mathrm{t})$ goes to plateau because all peptide molecules already adsorbed on dendrimer. The average value of $(\mathrm{N}(\mathrm{t})$ for time $\mathrm{t}>40 \mathrm{~ns}$ gives average value of number of hydrogen bonds between dendrimer and peptide moleculesin equilibrium state. This function was also calculated using g_hbonds function of GROMACS.

\section{EQUILIBRIUM COMPLEX}

Equilibrium values of $\mathrm{R}_{\mathrm{g}}(\mathrm{t})$ of dendrimer in complex and $\mathrm{R}_{\mathrm{g}}(\mathrm{t})$ of whole complex are shown in table 1. It is easy to see that the size of the complex of G2 with 8EDR and 16 EDR peptides is in 1.62 and in 1.93 times larger than the size of the dendrimer G2 itself (see table 1). It is quite natural, that complexes has larger sizes than dendrimer since size correlates with the molecular weight of the complex compared to the molecular weight of the individual dendrimer. The shape of complex can be characterized by main component ratio $\left(R g^{11}, R g^{22}\right.$, $R g^{33}$ ) of tensor of inertia of the system. We used the ratio of longest and shortest components: $R_{g}{ }^{33} / R_{g}{ }^{11}$ as estimation of anisotropy of our complex. For dendrimer G2 this value is equal to 1.43 , for the complex of G2 with 8 EDR peptides it is equal to 1.64 and for G2 with 16 EDR peptides - 1.46. Thus the shapes of dendrimer and complex slightly deviate from spherical shape and are similar in all subsystems. These deviations are not big so we can treat both systems as nearly spherical objects in the rest of the paper and study their radial density distribution function.

TABLE $1 . R_{g}{ }^{11}, R_{g}{ }^{22}, R_{g}{ }^{33}, R_{g}$ of tensor of inertia of dendrimer of second generation $\mathrm{G} 2$ and of complexes of G2 with 8EDR and G2 with 16EDR

\begin{tabular}{lccccc} 
System & $\mathrm{R}_{\mathrm{g}}{ }^{11}$ & $\mathrm{R}_{\mathrm{g}}{ }^{22}$ & $\mathrm{R}_{\mathrm{g}}{ }^{33}$ & $\mathrm{R}_{\mathrm{g}}, \mathrm{nm}$ & $\mathrm{R}_{\mathrm{g}}{ }^{33} / \mathrm{R}_{\mathrm{g}}{ }^{11}$ \\
\hline $\mathrm{G} 2$ & 0.69 & 0.92 & 0.99 & 1.07 & 1,43 \\
$\mathrm{G} 2+$ 8EDR & 0.99 & 1.51 & 1.62 & 1.73 & 1.64 \\
$\mathrm{G} 2+16 E D R$ & 1.31 & 1.74 & 1.91 & 2.06 & 1.46 \\
\hline
\end{tabular}

Information about the internal structure of the equilibrium complex could be obtained using radial density distribution function of different subsystem 
of atoms relatively center of inertia of system. They were calculated using g_rdf function of GROMACS. Fig. 4 demonstrates that atoms of dendrimer (curve 2, fig.4) are located mainly in the center of the complex (close to radial distance $r=0$ $\mathrm{nm}$ ). Peptides atoms (curve 1, fig. 4) could slightly penetrate into dendrimer but two maxima of their density (near $\mathrm{r}=0.6 \mathrm{~nm}$ and $1.0 \mathrm{~nm}$ ) and both curve have similar long tails. It means that peptide molecules are always in outer shell of dendrimer.

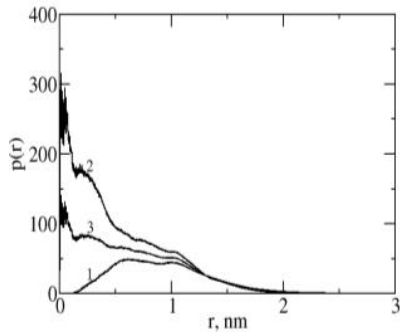

(a)

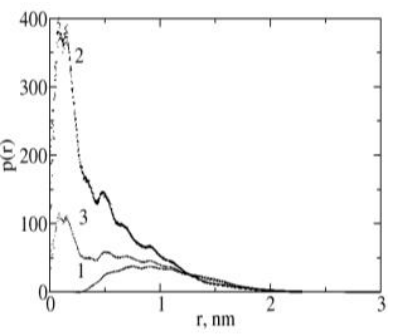

(b)
Fig.4 Radial distribution p(r) curves for complex of dendrimer G2 and 8EDR (a) or G2 and 16 EDR (b) lines for peptide atoms (1); for dendrimer atoms (2); and for all atoms of complex (3).

\section{CONCLUSION}

In this study the process of complex formation in system consisting of lysine dendrimer of second generation and 8 or 16 EDR peptides was studied. It was shown that stable dendrimer-peptide complex forms within 30-40 ns in both systems. Radial density distribution for atoms of dendrimer and peptide molecules are rather different: atoms of dendrimer are mainly in the center of complex while peptide molecules are mainly on its surface and their radial distribution have broad maximum between 0.5 and $1.5 \mathrm{~nm}$ for both systems.

\section{ACKNOWLEDGMENTS}

The research is carried out using the equipment of the shared research facilities of HPC computing resources at Lomonosov Moscow State University [68]. I.M.N. is supported by Government of Russian Federation (subsidy 08-08). I.I.Tarasenko worked accordingly to State Assingment of IMC RAS.

\section{REFERENCES}

[1] V.Khavinson, N.Linkova, E.Kukanova et al. J Neurol Neurosci., 8, 1-11 (2016).

[2] V.H. Khavinson, N.G.Lopatina, N.I.Chalisova, et al., Fundamental Research, 2(3), 492-496 (2015)

[3] B. Hess, C. Kutzner, D. Van Der Spoel, E. Lindahl, J. Chem. Theory and Comput., 4, 435-447 (2008).
[4] V.Hornak, R.Abel, A.Okur, D.Strockbine, A.Roitberg, C.Simmerling, Proteins:, 65, 712-725 (2006)

[5] A.A. Darinskii, Y.Y. Gotlib, A.V. Lyulin, I.M. Neelov, Vysokomolekulyarnye Soedineniya, Ser.A, 22(1), 123-132 (1980).

[6] A.A. Darinskii, Y.Y. Gotlib, A.V. Lyulin, I.M. Neelov, Vysokomolekulyarnye Soedineniya, Ser.A, 33(6), 1211-1220 (1991).

[7] A.A. Darinskii, Y.Y. Gotlib, A.V. Lyulin, I.M. Neelov, Polymer Science, 34, 11-15 (1992

[8] A. Darinskii, Y. Gotlib, M. Lukyanov, A.Lyulin, I. Neelov, Application of Scattering Methods to the Dynamics of Polymer Systems, Progr. in Colloid \& Polymer Sci, 91, 13-15 (1993).

[9] A. Darinskii, A. Lyulin, I. Neelov, Makromolekulare Chemie-Theory and Simulations (Macromol.Theory \& Simulations), 2, 523-530 (1993).

[10] I. Neelov, K. Binder, Macromolecular theory and simulations , 4(6), 1063-1084 (1995)

[11] I.M. Neelov, K. Binder, Macromolecular Theory and Simulations, 4(1), 119-136 (1995)

[12] J. Ennari, M. Elomaa, I. Neelov, F. Sundholm, Polymer, 41, 985-990 (2000).

[13] J. Ennari, I. Neelov, F. Sundholm, Polymer, 41, 2149-2155 (2000).

[14] J. Ennari, I. Neelov, F. Sundholm, Comput. Theor. Polym. Sci., 10, 403-410 (2000).

[15] J. Ennari, I. Neelov, F. Sundholm, Polymer, 41, 4057-4063 (2000).

[16] J. Ennari, I. Neelov, F. Sundholm, Polymer, 42, 8043-8050 (2001).

[17] J. Ennari, I. Neelov, F. Sundholm, Polymer, 45, 4171-4179 (2004).

[18] I.M. Neelov, D.B. Adolf, A.V. Lyulin, G.R. Davies, Journal of Chemical Physics, 117, 40304041 (2002)

[19] P.F. Sheridan, D.B. Adolf, A.V. Lyulin, I. Neelov, G.R. Davies, Journal of Chemical Physics, 117, 7802-7812 (2002).

[20] I.M. Neelov, D.B. Adolf, J. Phys. Chem. B., $108,7627-7636$ (2004).

[21] I.M. Neelov, D.B. Adolf, Macromolecules, 36, 6914-6924 (2003).

[22] M.A. Mazo, M.Y. Shamaev, N.K. Balabaev, A.A.Darinskii, I.M.Neelov, Physical Chemistry and Chemical Physics, 6, 1285-1289 (2004).

[23] I.M. Neelov, D.B. Adolf, T.C.B. McLeish, E. Paci. Biophysical Journal, 91, 3579-3588 (2006).

[24] S.G. Falkovich, I.M. Neelov, A.A. Darinskii, Polymer Science Series A, 52 (6), 662-670 (2010)

[25] I.M. Neelov, D.A. Markelov, S.G. Falkovich, M.Yu. Ilyash., B.M. Okrugin, A.A. Darinskii, 
Vysokomolec. Soed. Ser. A , 55, 963-970 (2013) (Polymer Science Series C, 55(1), 154-161(2013). [26] S. Falkovich, D. Markelov, I. Neelov, A. Darinskii, Journal of Chemical Physics, 139, 064903 (2013).

[27] I. Neelov, S. Falkovich, D. Markelov, E. Paci, A. Darinskii, H. Tenhu, in: Dendrimers in Biomedical Applications, Eds. London: Royal Society of Chemistry, 2013, 99-114.

[28] I.M. Neelov, A. Janaszewska, B. Klajnert, M. Bryszewska, N. Makova, D. Hicks, H. Pearson, G.P. Vlasov, M.Yu Ilyash, D.S. Vasilev, N.M. Dubrovskaya, N.L. Tumanova, I.A. Zhuravin, A.J. Turner, N.N. Nalivaeva, Current Medical Chemistry, 20, 134-143 (2013).

[29] V. E. Yudin, I.P. Dobrovolskaya, I.M. Neelov et al., Carbohydrate Polymers, 108, 176-182 (2014).

[30] D.A Markelov, S.G. Falkovich, I.M. Neelov, M.Yu Ilyash, V.V Matveev, E. Lahderanta, P. Ingman, A.A. Darinskii, Physical Chemistry Chemical Physics, 17, 3214-3226 (2015).

[31] O.V. Shavykin, I.M. Neelov, A.A. Darinskii, Physical Chemistry and Chemical Physics, 18, 24307-24317 (2016).

[32] I.M. Neelov, A.A. Mistonova, A.Yu Khvatov, V.V. Bezrodny, Nauchno-Tekhnicheskii Vestnik Informatsionnykh Tekhnologii, Mekhaniki i Optiki (Scientific and Technical Journal of Information Technologies, Mechanics and Optics), 14(4), 169175 (2014).

[33] E.V. Popova, O.V. Shavykin, I.M. Neelov, F. Leermakers, Nauchno-Tekhnicheskii Vestnik Informatsionnykh Tekhnologii, Mekhaniki i Optiki (Scientific and Technical Journal of Information Technologies, Mechanics and Optics), 16(4), 716724 (2016).

[34] O.V. Shavykin, E.V. Popova, A.A. Darinskii, I.M. Neelov, F. Leermakers, NauchnoTekhnicheskii Vestnik Informatsionnykh Tekhnologii, Mekhaniki i Optiki (Scientific and Technical Journal of Information Technologies, Mechanics and Optics), 16(5), 893-902 (2016).

[35] M.Yu. Ilyash, D.N. Khamidova, B.M. Okrugin, I.M. Neelov, WSEAS Transaction on Biology and Biomedicine, 12, 79-86 (2015).

[36] I. Neelov, M. Ilyash, S. Falkovich, A. Darinskii, in Synthesis, Characterization and Modelling of Nano-Sized Structures, Eds. Nova Publisher, 2016, p.147-156.

[37] B.M. Okrugin, I.M. Neelov, F.A.M. Leermakers, O.V. Borisov, Polymer, 125, 292-302 (2017)

[38] J. Gowdy, M. Batchelor, I. Neelov, E. Paci, The Journal of Physical Chemistry B, 121, 95189525 (2017).
[39] I. Neelov, E. Popova, WSEAS Transaction on Biology and Biomedicine, 14, 75-82 (2017).

[40] O. V. Shavykin, F. A. M. Leermakers, I. M. Neelov, A. A. Darinskii Langmuir, 34,1613-1626 (2018).

[41] I. Neelov, E. Popova, International J. of Materials, 4, 16-21 (2017).

[42] I. Neelov, E. Popova, Proceedings - 2016 3rd International Conference on Mathematics and Computers in Sciences and in Industry, MCSI, 2729.08.2016 Chania, Greece, 66-71 (2016).

[43] E. Popova, B. Okrugin, I. Neelov, Natural Science, 8, 499-510 (2016).

[4] I.M. Neelov, E.V Popova, International Journal of Biology and Biomedicine, 2, 6-12 (2017).

[45] I.M.Neelov E.V.Popova International Journal of Materials, 4, 16-21 (2017).

[46] I.M. Neelov, E.V Popova, D.N. Khamidova, I.I. Tarasenko, International Journal of Biochemistry Research, 2, 28-33 (2017).

[47] Y.Y.Gotlib, N.K.Balabaev, A.A.Darinskii, I.M. Neelov Macromolecules, 13, 602-608 (1980).

[48] Y.Y.Gotlib, A.A.Darinskii, L.I.Klushin, I.M.Neelov, Acta Polymerica, 35, 124-129 (1984)

[49] A.V.Lyulin, M.S.Al-Barwani, M.P. Allen, I.M.Neelov Macromolecules, 31, 4626-4634 (1998).

[50] I.M.Neelov, O.V. Borisov, R. Binder, Macromolecular Theory and Simulations, 7, 141156 (1998)

[51] I.M.Neelov, O.V. Borisov, R. Binder, Journal of Chemical Physics, 108, 6973-6988 (1998).

[51] R.M.Dammert, S.L. Maunu, F.H.J. Maurer, I.M.Neelov, Macromolecules, 32, 1930-1938 (1999) [52] P.F.Sheridan, D.B.Adolf, A.V.Lyulin, I.M.Neelov, Journal of Chemical Physics, 117, 7802-7812 (2002)

[53] O.V.Shavykin, I.V.Mikhailov, A.A.Darinskii, I.M.Neelov, F.A.M.Leermakers, Polymer, 146, 256266 (2018)

[54] B. Okrugin, M.Ilyash, D.Markelov, I.Neelov, Pharmaceutics, 10(3), 129 (2018)

[55] N.N.Sheveleva, D.A.Markelov, M.A.Vovk, M.E.Mikhailova, I.I.Tarasenko, I.M.Neelov, E.Lähderanta, Scientific Reports 8(1), 8916 (2018)

[56] E.B.Zhulina, I.M.Neelov, S.S.Sheiko O.V.Borisov, Polymer Science, Series C, 60, 76-83 (2018)

[57]B.M.Okrugin, R.P., Richter, F.A.M.Leermakers, I.M.Neelov, O.V.Borisov, E.B.,Zhulina, Soft Matter 14(30), 6230-6242 (2018)

[58] A.A.Darinskii, A.Zarembo, N.K.Balabaev, I.M.Neelov, F.Sundholm, Phys.Chem.Chem.Phys., $5,2410(2003)$ 
[59] I.M.Neelov, O.V.Shavykin, M.Yu.Ilyash et al. Supercomputing Frontiers and Innovations 5, 60-64 (2018)

[60] N.N.Sheveleva, D.A.Markelov, M.A.Vovk, I.M.Neelov, E.Lähderanta, RSC Adv. 9(31), 18018 (2018)

[61] N.N.Sheveleva, D.A.Markelov, M.A.Vovk, I.I.Tarasenko, M.E. Mikhailova, M.Yu. Ilyash, I.M. Neelov, Molecules, 24 2481(2019)

[62]I.Neelov, D.Khamidova, V.Bezrodnyi, S.Mikhtaniuk, Int. J Biol. and Biomed. Eng. 13, 2631 (2019)

[63] D.N.Khamidova, V.V.Bezrodnyi, I.M. Neelov, E.V.Popova, Int. J Biol. and Biomed. Eng. 12, 45-58 (2018)
[64] I.Neelov, E.Popova, D.Khamidova, F.Komilov, Int. J Biol. and Biomed. Eng. 11, 95-100 (2017)

[65] D.N.Khamidova, V.V.Bezrodnyi, I.M. Neelov, E.V.Popova, Int. J Biol. and Biomed. Eng. 12, 7-17 (2018)

[66] I.Neelov, E.Popova, D. Khamidova, I.Tarasenko, Int. J Biol. and Biomed. Eng. 11, 194203 (2017)

[67] M Gorzkiewicz, M Konopka, A Janaszewska, II Tarasenko, NN Sheveleva, Bioorganic Chemistry 95,103504

[68] V.Sadovnichy, A.Tikhonravov, V.Voevodin, V.Opanasenko, Contemporary High Performance Computing: From Petascale Toward Exascale, 283307, CRC Press, Boca Raton, FL (2013) 